\title{
Pengaruh PAD dan Dana Perimbangan terhadap Kinerja Keuangan Pemerintah Kabupaten/Kota di Sumatera Selatan
}

\author{
Verawaty \\ Universitas Bina Darma \\ Email:verawaty@binadarma.ac.id \\ Ade Kemala Jaya \\ Universitas Bina Darma \\ Email: adekemala@binadarma.ac.id \\ Intan Puspanita \\ Universitas Bina Darma \\ Email: intan.puspanita@binadarma.ac.id \\ Nurhidayah \\ Universitas Bina Darma \\ Email: nurhidayah.ismun@gmail.com
}

\begin{abstract}
The financial performance of a regional government is the ability of a region to explore the financial potential of the region as well as to manage the local financial resources in order to meet the needs of the regional government so that it does not depend on the funding from the central government. This study was aimed to analyze whether fiscal balance transfers such as local own-source revenue, general allocation funds, special allocation funds, and revenue sharing funds might affect the government's financial performance. The study used quantitative analysis techniques with multivariate regression. The object of this research was the district and city governments in South Sumatra in 2014-2016. The results showed that local own-source revenue had a positive effect on the financial performance of local governments. However, there were negative effects of general and special allocation funds on regional government financial performance. For revenue sharing funds, it did not affect financial performance. This means, the greater the contribution of local own-source revenue to finance development and community services the greater increase in the financial performance of local governments. The higher the amount of general allocation funds received from the center, the lower the financial performance of local governments. The large flow of special allocation funds can provide opportunities for budget leakage, which can result in a decrease in the financial performance of local governments.
\end{abstract}

Keywords: local own-source revenue, fiscal balance transfers, local government financial performance

\begin{abstract}
Abstrak
Kinerja keuangan pemerintah daerah merupakan kemampuan suatu daerah dalam menggali potensi keuangan daerah serta mengelola sumber-sumber keuangan asli daerah guna memenuhi kebutuhan pemerintah daerah agar tidak bergantung pada pembiayaan dari pemerintah pusat. Penelitian ini bertujuan untuk menganalisis apakah dana perimbangan, antara lain pendapatan asli daerah (PAD), dana alokasi umum (DAU), dana alokasi khusus (DAK), dan dana bagi hasil (DBH) berpengaruh terhadap kinerja keuangan pemerintah. Penelitian menggunakan teknik analisis kuantitatif, yaitu multivariate regression. Objek pada penelitian ini yaitu pemerintah kabupaten dan kota di Sumatera Selatan tahun 2014-2016. Hasil penelitian menunjukkan PAD berpengaruh positif terhadap kinerja keuangan pemerintah daerah. Namun terdapat pengaruh negatif DAU dan DAK terhadap Kinerja Keuangan Pemerintah Daerah. Adapun DBH tidak mempengaruhi kinerja keuangan. Hal ini berarti, semakin besar kontribusi PAD untuk membiayai pembangunan dan pelayanan masyarakat, terjadi peningkatan kinerja keuangan pemerintah daerah. Semakin tinggi besaran DAU yang diterima dari pusat maka semakin rendah kinerja keuangan pemerintah daerah. Banyaknya aliran DAK dapat memberikan peluang terjadinya kebocoran anggaran, sehingga dapat mengakibatkan adanya penurunan kinerja keuangan pemerintah daerah.
\end{abstract}

Kata Kunci: PAD, dana perimbangan, kinerja keuangan pemerintah daerah 


\section{Pendahuluan}

Sejak diterapkannya otonomi daerah di Indonesia, paradigma pengelolaan keuangan daerah mengalami perubahan yang sangat mendasar. Undang-Undang No. 32 Tahun 2004 dan Undang-Undang No. 33 Tahun 2004 dijadikan sebagai landasan utama dalam melaksanakan sistem desentralisasi agar tujuan dari otonomi daerah tercapai. Melalui paket undang-undang tersebut, seluruh pemerintah daerah di Indonesia, diberikan hak, wewenang dan tanggung jawab untuk mengatur dan mengurus sendiri urusan pemerintahan dan kepentingan masyarakat setempat sesuai dengan peraturan perundangundangan. Dalam sudut pandang keuangan negara, otonomi daerah memberikan kewenangan besar kepada pemerintah daerah untuk menyelenggarakan kegiatan pemerintahan dan mengelola sumber-sumber keuangan (Sumarsono, 2010).

Kebijakan desentralisasi dan otonomi daerah yang dimulai dilaksanakan sejak tahun anggaran 2001 merupakan peluang bagi pemerintah daerah di Indonesia untuk melaksanakan serta membiayai sendiri kemajuan pembangunan di daerahnya masingmasing. Sesuai dengan hasil penelitian serta evaluasi terhadap pelaksanaan Anggaran Pendapatan dan Belanja Pemerintah Daerah (APBD), hanya beberapa daerah yang tergolong kaya yang mampu membiayai sendiri proyek-proyek pembangunannya. Filosofi pengelolaan keuangan dalam pemerintahan adalah bekerja untuk kesejahteraan masyarakat, bukan pegawai. Oleh karena itu, efektivitas keuangan harus jelas, yaitu untuk kemakmuran masyarakat melalui daya beli masyarakat yang naik, tersedia banyak yang lapangan kerja sehingga penghasilan menaik, pelayanan yang baik dan murah, serta tersedianya jaminan kesehatan.

Pengukuran kinerja keuangan menurut Halim (2012), dapat diukur dengan membandingkan hasil yang dicapai dari satu periode dengan periode sebelumnya sehingga dapat diketahui bagaimana kecenderungan yang terjadi. Selain membandingkan, pengukuran kinerja juga dapat menggunakan empat rasio yang dapat dijadikan sebagai tolak ukur dalam kinerja keuangan pemerintah, yaitu rasio kemandirian, rasio efektivitas, rasio efisiensi, dan rasio aktivitas.

Pemerintah daerah sebagai pelaksana tugas pemerintahan di daerah berperan sebagai manajer keuangan daerah dalam rangka mencapai tujuan daerah berdasarkan peraturan perundangan (Mardiasmo, 2009). Kemampuan daerah dalam mencapai tujuan itu disebut dengan kinerja keuangan daerah. Menurut Verawaty (2017), kemampuan suatu daerah dalam menggali potensi keuangan daerah serta mengelola sumber-sumber keuangan asli daerah guna memenuhi kebutuhan pemerintah daerah harus dilakukan agar tidak bergantung pada pembiayaan dari pemerintah pusat merupakan salah satu tolak ukur kinerja keuangan pemerintah daerah. Pemerintah daerah, baik di tingkat provinsi maupun kabupaten/kota dalam penyelenggaraan otonomi daerah wajib melaporkan pertanggungjawaban keuangan daerah sebagai dasar penilaian kinerja keuangannya. Suatu manajemen harus selalu dinilai dalam mencapai tujuan tersebut.

Penilaian kinerja pemerintah merupakan bagian dari sistem pengendalian. Penilaian kinerja dilakukan untuk mengetahui tingkat efisiensi dan efektivitas organisasi dalam mencapai tujuan yang telah ditetapkan. Dalam tahap penilaian kinerja, akuntansi manajemen berperan dalam pembuatan indikator kinerja kunci (key performance 
indicator) dan satuan ukur untuk masing-masing aktivitas yang dilakukan (Mardiasmo, 2009).

Berdasarkan hasil pemeriksaan audit dalam Ikhtisar Hasil Pemeriksaan Semester I (2017), secara terperinci BPK-RI mengungkapkan bahwa terdapat 9.729 temuan yang terdiri dari 14.997 permasalahan. Dari 14.997 permasalahan terdapat 164 permasalahan ketidakhematan, ketidakefisienan, dan ketidakefektifan senilai Rp 2,25 triliun. Dari 164 permasalahan terdapat 12 (7\%) permasalahan ketidakhematan senilai Rp 11.96 miliar, 30 (18\%) permasalahan ketidakefisienan senilai Rp 574.31 miliar dan 122 (75\%) permasalahan ketidakefektifan senilai Rp 1.67 triliun. Jika dalam suatu daerah terdapat banyak permasalahan ketidakhematan, ketidakefisienan, dan ketidakefektifitas, kinerja keuangan yang ada pada daerah tersebut dianggap belum baik.

Salah satu instrumen untuk menilai kinerja pemerintah daerah dalam mengelola keuangan daerah adalah dengan melakukan rasio keuangan terhadap APBD yang telah ditetapkan dan disahkan. Menurut Halim (2012), pengelolaan keuangan daerah yang transparan, jujur, demokratis, efektif, efisien dan akuntabel, salah satunya dengan menggunakan rasio kemandirian keuangan daerah. Rasio ini menunjukkan kemampuan keuangan pemerintah daerah dalam membiayai sendiri kegiatan pemerintahan, pembangunan dan pelayanan kepada masyarakat, yang diukur dengan rasio Pendapatan Asli Daerah (PAD) terhadap jumlah bantuan pemerintah pusat dan pinjaman, sehingga dapat diketahui tingkat kemampuan daerah dalam mencapai target pendapatan daerahnya. Dalam penelitian ini, faktor-faktor yang diasumsikan memiliki pengaruh terhadap kinerja keuangan adalah PAD dan dana perimbangan, yaitu Dana Alokasi Umum (DAU), Dana Alokasi Khusus (DAK), dan Dana Bagi Hasil (DBH).

Banyak penelitian yang sudah dibuat mengenai pengaruh PAD dan dana perimbangan terhadap kinerja pemerintah daerah di Indonesia tetapi dalam penelitian ini diharapkan akan menjelaskan lebih rinci bagaimana kinerja pemerintah Provinsi Sumatera Selatan dalam kasus tersebut. PAD dibagi menjadi beberapa aspek, yaitu retribusi daerah, hasil pengelolaan kekayaan daerah, pajak daerah, serta lainnya. Adapun untuk pendanaan perimbangan, yaitu DAU, DAK, dan DBH. Untuk itu dana perimbangan akan dijelaskan lebih rinci satu per satu. Adapun untuk PAD dijadikan satu kesatuan.

\section{Literature Review}

\subsection{Teori Keagenan}

Menurut Halim (2012), teori keagenan merupakan suatu hubungan yang terjalin berdasarkan kontrak perjanjian antara dua pihak atau lebih dimana pihak pertama disebut prinsipal dan pihak yang lainnya disebut dengan agen. Prinsipal merupakan pihak yang bertindak sebagai pemberi perintah dan bertugas untuk mengawasi, memberikan penilaian dan masukan atas tugas yang telah dijalankan oleh agen. Adapun agen adalah pihak yang menerima dan menjalankan tugas sesuai dengan kehendak prinsipal.

Verawaty (2017) meyakini bahwa teori keagenan dapat diterapkan dalam organisasi publik. Model agen prinsipal merupakan kerangka analitik yang sangat berguna dalam menjelaskan masalah insentif dalam institusi publik dengan dua kemungkinan kondisi, yakni terdapat beberapa prinsipal dengan masing-masing tujuan dan kepentingan yang 
tidak koheren dan prinsipal juga bisa bertindak tidak sesuai dengan kepentingan masyarakat, tetapi mengutamakan kepentingan yang sifatnya lebih sempit. Hubungan keagenan dalam pemerintah dijalankan berdasarkan peraturan pemerintah daerah dan bukan semata-mata hanya untuk memenuhi kepentingan prinsipal saja.

Jika dikaitkan dengan kinerja keuangan daerah, pemerintah pusat merupakan prinsipal dimana pemerintah pusat adalah pihak yang bertindak sebagai pemberi perintah dan bertugas untuk mengawasi, memberikan penilaian dan masukan atas tugas yang telah dijalankan oleh pemerintah daerah. Jika kinerja keuangan daerah yang dikelola oleh pemerintah daerah baik, kemampuan suatu daerah untuk mengelola sumber-sumber keuangan asli daerah guna memenuhi kebutuhannya juga akan tercukupi dan tidak bergantung sepenuhnya kepada pemerintah pusat.

\subsection{Teori Anggaran}

Anggaran merupakan alat akuntansi yang dapat membantu pimpinan entitas dalam merencanakan dan mengendalikan operasi entitas. Anggaran memperhatikan bagaimana sumber daya yang diharapkan akan diperoleh dan dipakai selama periode waktu tertentu. Menurut Mardiasmo (2009), anggaran merupakan pernyataan mengenai estimasi kinerja yang hendak dicapai selama periode waktu tertentu yang dinyatakan dalam ukuran finansial. Adapun penganggaran adalah proses atau metode untuk mempersiapkan suatu anggaran. Verawaty (2017), menyatakan APBD yang sehat dalam hal ini tidak defisit, akan mendukung pencapaian target-target pembangunan secara optimal.

Jika dikaitkan dengan DAU, pemerintah pusat akan menyusun Anggaran Pendapatan Belanja Nasional (APBN) yang akan dialokasikan kepada keuangan daerah dalam rangka pelaksanaan desentralisasi. DAK yang diberikan oleh pemerintah pusat melalui Anggaran Pendapatan Belanja Nasional (APBN) akan digunakan untuk kegiatan khusus dan DBH dimana pemerintah menyusun rencana yang digunakan untuk kebutuhan daerah dalam rangka desentralisasi dari DBH pajak dan sumber daya alam.

\subsection{Kinerja Keuangan Daerah}

Menurut Mahmudi (2010), secara umum pengukuran kinerja menunjukkan hasil dari implementasi sebuah kegiatan/kebijakan, tetapi pengukuran kinerja tidak menganalisis alasan hal ini dapat terjadi atau mengidentifikasi perubahan yang perlu dilakukan terhadap tujuan dari kegiatan/kebijakan. Menurut Mardiasmo (2009), pengukuran kinerja adalah suatu sistem yang bertujuan untuk membantu manajer publik menilai pencapaian suatu strategi melalui alat ukur finansial dan nonfinansial. Jadi, pengukuran kinerja merupakan hal yang sangat penting untuk menilai prestasi manajer dan unit organisasi serta akuntabilitas dalam menghasilkan pelayanan publik yang lebih baik, yaitu tidak hanya sekedar kemampuan menunjukkan bahwa uang publik tersebut digunakan secara ekonomis, efisien, dan efektif serta sesuai anggaran yang telah dibuat. Verawaty (2014) menyimpulkan bahwa akuntabilitas atas suatu anggaran yang meningkat, pemerintah daerah pasti akan menghadapi peningkatan permintaan untuk memantau informasi dan insentif yang lebih besar untuk memberi sinyal kinerja.

Secara umum tujuan pengukuran kinerja menurut Mardiasmo (2009) adalah:

1. Untuk mengkomunikasikan strategi secara lebih baik. 
2. Untuk mengukur kinerja finansial dan nonfinansial secara berimbang sehingga dapat ditelusuri perkembangan pencapaian strategi.

3. Untuk mengakomodasikan pemahaman kepentingan manajer level menengah dan bawah serta memotivasi untuk mencapai tujuan.

4. Sebagai alat untuk mencapai kepuasan berdasarkan pendekatan individual dan kemampuan kolektif yang rasional.

Selain itu manfaat dari pengukuran kinerja, menurut Mardiasmo (2009) adalah:

1. Memberikan pemahaman mengenai ukuran yang digunakan untuk menilai kinerja manajemen.

2. Memberikan arah untuk mencapai target kinerja yang telah ditetapkan.

3. Untuk memonitor dan mengevaluasi pencapaian kinerja dan membandingkannya dengan target kinerja serta melalukan tindakan korektif untuk memperbaiki kinerja.

4. Sebagai dasar untuk memberikan penghargaan dan hukuman (reward dan punishment) secara objektif atas pencapaian prestasi yang diukur sesuai dengan sistem pengukuran kinerja yang telah disepakati.

5. Sebagai alat komunikasi antara bawahan dan pimpinan dalam rangka memperbaiki kinerja organisasi.

6. Membantu mengidenfikasikan apakah kepuasan pelanggan sudah terpenuhi

7. Memastikan bahwa pengambilan keputusan dilakukan secara objektif.

Analisis rasio keuangan pada APBD dilakukan dengan cara membandingkan hasil yang dicapai dari periode dengan periode sebelumnya sehingga dapat diketahui bagaimana kecenderungan yang terjadi. Menurut Halim (2012), analisis rasio keuangan APBD terdiri dari berbagai bentuk, di antaranya rasio derajat desentralisasi fiskal. Mahmudi (2010) mengatakan bahwa derajat desentralisasi dihitung berdasarkan perbandingan antar jumlah PAD dengan jumlah penerimaan daerah. Rasio ini menunjukkan derajat kontribusi PAD terhadap total penerimaan daerah. Semakin tinggi kontribusi PAD, maka semakin tinggi kemampuan pemerintah daerah dalam menyelenggarakan desentralisasi. Ini menunjukkan tingkat kewenangan dan tanggung jawab yang diberikan pemerintah pusat kepada pemerintah daerah untuk melaksanakan pembangunan (Verawaty, 2017).

Dengan demikian, dapat disimpulkan bahwa PAD merupakan aspek yang sangat menentukan keberhasilan suatu daerah dalam menyelenggarakan desentralisasi. Semakin tinggi PAD, maka semakin besar kemampuan keuangan daerah untuk membiayai belanja pemerintah dalam menjalankan roda pemerintahan.

\section{Metode Penelitian}

\subsection{Populasi dan Sampel}

Populasi dalam penelitian ini adalah seluruh kabupaten/kota di Provinsi Sumatera Selatan dari tahun 2014-2016. Metode pemilihan sampel pada penelitian ditentukan dengan metode purposive sampling yang bertujuan agar memperoleh sampel yang representatif. Adapun kriteria yang digunakan sebagai berikut:

1. Kabupaten dan kota yang telah menyajikan laporan realisasi APBD.

2. Kabupaten dan kota yang membuat dan menyajikan laporan realisasi APBD dalam format ASP dan yang terdaftar di situs www.djpk.depkeu.go.id tahun 2014-2016. 
3. Kabupaten dan kota yang melaporkan anggaran dari sektor PAD dengan nilai minimal 10 miliar rupiah.

Berikut merupakan deskripsi penarikan sampel penelitian:

Tabel 1. Deskripsi Penarikan Sampel Penelitian

\begin{tabular}{|c|l|c|c|}
\hline No. & \multicolumn{1}{|c|}{ Keterangan } & Jumlah & Frekuensi \\
\hline 1 & $\begin{array}{l}\text { Merupakan pemerintah kota/kabupaten di Provinsi } \\
\text { Sumatera Selatan }\end{array}$ & 17 & $100 \%$ \\
\hline 2 & PAD Minimal 10 Miliar & $(1)$ & $17 \%$ \\
\hline $\begin{array}{l}\text { Jumlah pemerintah kota/kabupaten yang menjadi sampel } \\
\text { penelitian }\end{array}$ & 16 & $83 \%$ \\
\hline Periode penelitian (tahun 2014-2016) & 3 & - \\
\hline \multicolumn{2}{|l|}{ Total sampel } & 48 & $83 \%$ \\
\hline
\end{tabular}

Dari populasi sebanyak 17 provinsi hanya ada 16 provinsi yang memenuhi kriteria tersebut. Peneliti tidak menggunakan kabupaten PALI sebagai sampel karena provinsi ini baru berdiri tahun 2013. Berikut merupakan sampel penelitian:

Tabel 2. Sampel Penelitian

\begin{tabular}{|c|l|}
\hline No & Kabupaten/Kota \\
\hline 1 & Kabupaten Lahat \\
\hline 2 & Kabupaten Musi Banyuasin \\
\hline 3 & Kabupaten Musi Rawas \\
\hline 4 & Kabupaten Muara Enim \\
\hline 5 & Kabupaten Ogan Komering Ilir \\
\hline 6 & Kabupaten Ogan Komering Ulu \\
\hline 7 & Kota Palembang \\
\hline 8 & Kota Prabumulih \\
\hline 9 & Kota Pagar Alam \\
\hline 10 & Kota Lubuk Linggau \\
\hline 11 & Kabupaten Banyuasin \\
\hline 12 & Kabupaten Ogan Ilir \\
\hline 13 & Kabupaten OKU Timur \\
\hline 14 & Kabupaten OKU Selatan \\
\hline 15 & Kabupaten Empat Lawang \\
\hline 16 & Kabupaten Musi Rawas Utara \\
\hline
\end{tabular}

\subsection{Operasional Variabel}

Menurut Indriantoro dan Supomo (2011), operasional variabel adalah penentuan construct sehingga menjadi variabel yang dapat diamati dan diukur dengan menentukan hal yang diperlukan untuk mencapai tujuan tertentu. Penelitian ini dilakukan untuk mengetahui pengaruh kinerja keuangan pemerintah daerah di Provinsi Sumatera Selatan dengan menggunakan variabel dependent (terikat) dan empat variabel independent (bebas). Variabel terikat dalam penelitian ini, yaitu kinerja keuangan pemerintah daerah, 
sedangkan variabel bebas terdiri dari PAD, DAU, DAK, dan DBH. Berikut merupakan tabel operasional variabel:

Tabel 3. Tabel Operasional Variabel

\begin{tabular}{|c|c|c|c|}
\hline Variabel & Definisi & Indikator & $\begin{array}{l}\text { Skala } \\
\text { Ukur }\end{array}$ \\
\hline $\begin{array}{l}\text { Variabel } \\
\text { Dependen: } \\
\text { Kinerja Keuangan } \\
\text { Pemerintah Daerah }\end{array}$ & $\begin{array}{l}\text { Kinerja keuangan pemerintah } \\
\text { daerah adalah kemampuan suatu } \\
\text { daerah untuk menggali dan } \\
\text { mengelola sumber-sumber } \\
\text { keuangan asli daerah dalam } \\
\text { memenuhi kebutuhannya guna } \\
\text { mendukung berjalannya sistem } \\
\text { pemerintahan, pelayanan } \\
\text { terhadap masyarakat dan } \\
\text { pembangunan daerahnya. }\end{array}$ & $\begin{array}{l}\text { PAD } \\
\text { dibandingkan } \\
\text { dengan total } \\
\text { Penerimaan } \\
\text { Daerah }\end{array}$ & Rasio \\
\hline $\begin{array}{l}\text { Variabel } \\
\text { Independen: } \\
\text { Pendapatan Asli } \\
\text { Daerah (PAD) }\end{array}$ & $\begin{array}{l}\text { PAD merupakan sumber } \\
\text { penerimaan daerah asli yang } \\
\text { digali di daerah tersebut untuk } \\
\text { digunakan sebagai modal dasar } \\
\text { pemerintah daerah dalam } \\
\text { membiayai pembangunan dan } \\
\text { usaha-usaha daerah untuk } \\
\text { memperkecil ketergantungan } \\
\text { dana dari pemerintah pusat. }\end{array}$ & $\begin{array}{l}\text { Pajak Daerah } \\
\text { (HPD), } \\
\text { Retribusi } \\
\text { Daerah (RD), } \\
\text { Hasil } \\
\text { Pengelolaan } \\
\text { Kekayaan } \\
\text { Daerah yang } \\
\text { Dipisahkan dan } \\
\text { Lain-lain PAD } \\
\text { yang sah }\end{array}$ & Nominal \\
\hline $\begin{array}{l}\text { 1. Dana Alokasi } \\
\text { Umum (DAU) }\end{array}$ & $\begin{array}{l}\text { DAU adalah transfer bersifat } \\
\text { umum yang jumlahnya sangat } \\
\text { signifikan dimana } \\
\text { penggunaannya menjadi } \\
\text { kewenangan daerah. }\end{array}$ & $\begin{array}{l}\text { Celah Fiskal dan } \\
\text { Alokasi Dasar }\end{array}$ & Nominal \\
\hline $\begin{array}{l}\text { 2. Dana Alokasi } \\
\text { Khusus (DAK) }\end{array}$ & $\begin{array}{l}\text { DAK merupakan salah satu dana } \\
\text { perimbangan yang menjadi } \\
\text { bagian dari sumber pendapatan } \\
\text { daerah. Ketentuan lebih lanjut } \\
\text { mengenai DAK diatur dengan } \\
\text { peraturan pemerintah. DAK } \\
\text { dialokasikan dari APBN kepada } \\
\text { daerah tertentu dalam rangka } \\
\text { pendanaan pelaksanaan } \\
\text { desentralisasi untuk mendanai } \\
\text { kegiatan khusus yang ditentukan } \\
\text { Pemerintah atas dasar prioritas } \\
\text { nasional, dan mendanai kegiatan }\end{array}$ & DAK & Nominal \\
\hline
\end{tabular}




\begin{tabular}{|c|l|l|l|}
\hline Variabel & \multicolumn{1}{|c|}{ Definisi } & \multicolumn{1}{|c|}{ Indikator } & $\begin{array}{l}\text { Skala } \\
\text { Ukur }\end{array}$ \\
\hline & $\begin{array}{l}\text { khusus yang diusulkan daerah } \\
\text { tertentu. }\end{array}$ & & \\
\hline 3. Dana Bagi & $\begin{array}{l}\text { DBH merupakan hak daerah atas } \\
\text { pengelolaan sumber-sumber } \\
\text { penerimaan negara yang } \\
\text { dihasilkan dari masing-masing } \\
\text { daerah, yang besarnya } \\
\text { ditentukan atas daerah penghasil } \\
\text { yang didasarkan atas ketentuan } \\
\text { perundangan yang berlaku. }\end{array}$ & $\begin{array}{l}\text { DBH pajak dan } \\
\text { DBH bukan } \\
\text { pajak (Sumber } \\
\text { Daya Alam) }\end{array}$ & Nominal \\
\end{tabular}

\subsection{Teknik Analisis}

Analisis regresi berganda (multivariative regression) merupakan suatu model dimana variabel terikat tergantung pada dua atau lebih variabel bebas. Analisis ini digunakan untuk mengetahui bagaimana variabel dependen dipengaruhi oleh satu atau lebih dari variabel independen dengan tujuan untuk mengestimasi atau memprediksi nilai rata-rata variabel dependen yang berdasarkan pada nilai variabel independen yang yang dipilih untuk diteliti. Dengan demikian, tujuan utama analisis regresi ini adalah untuk memprediksi nilai variabel dependen berdasarkan satu atau lebih variabel independen. Persamaan regresi yang digunakan dalam penelitian ini adalah:

$\mathrm{KKPD}=\alpha+\beta_{1} \mathrm{PAD}_{\mathrm{it}}+\beta_{2} \mathrm{DAU}_{\mathrm{it}}+\beta_{3} \mathrm{DAK}_{\mathrm{it}}+\beta_{4} \mathrm{DBH}_{\mathrm{it}}+\mathrm{e}_{\mathrm{it}}$

Keterangan:

KKPD : Kinerja Keuangan Pemerintah Daerah

$\alpha \quad$ : Konstanta

$\beta 1-\beta 4 \quad$ : Koefisien regresi (nilai peningkatan ataupun penurunan)

PAD : Pendapatan Asli Daerah

DAU : Dana Alokasi Umum

DAK : Dana Alokasi Khusus

DBH : Dana Bagi Hasil

$\mathrm{e}_{\text {it }}$ : Eror

Sebelum, uji hipotesis, dilakukan uji asumsi klasik, yaitu uji normalitas, multikolinearitas, heteroskedastisitas, dan autokorelasi. Adapun uji hipotesis yang dilakukan adalah uji koefisien determinasi (R2), Uji T (uji parsial), dan Uji F (uji simultan).

\section{Hasil dan Pembahasan}

\subsection{Uji asumsi klasik}

Semua variabel penelitian telah lolos uji asumsi klasik. Hasil uji normalitas, yaitu nilai Kolmogorov-Smirnov (K-S) dan nilai Asymp. Sig. (2-tailed) dengan seluruh variabel di atas $\alpha=0,05$ yang berarti data yang diuji terdistribusi normal. Hasil uji multikolinearitas menyatakan nilai tolerance untuk seluruh variabel lebih besar dari $10 \%$ dan VIF lebih kecil dari 10 yang berarti bahwa data penelitian ini tidak terjadi multikolinearitas. Hasil 
uji heteroskedastisitas menyatakan nilai signifikansi untuk setiap variabel bebas terhadap nilai absolute residual lebih besar dari 0,05 yang berarti bahwa tidak terjadi gejala heteroskedastisitas dalam penelitian ini. Hasil uji autokorelasi menyatakan nilai DW menunjukkan tidak terjadi autokorelasi.

\subsection{Statistik Deskriptif}

Berikut ini tabel statistik deskriptif untuk masing-masing variabel penelitian.

Tabel 4. Descriptive Statistics

\begin{tabular}{|l|r|r|r|r|r|}
\hline & N & Minimum & Maximum & \multicolumn{1}{c|}{ Mean } & \multicolumn{1}{c|}{ Std. Deviation } \\
\hline PAD & 48 & 23,21 & 27,38 & 25,1871 &, 90018 \\
\hline DAU & 48 & 25,60 & 27,89 & 27,0217 &, 45686 \\
\hline DAK & 48 & 21,41 & 26,74 & 25,0782 &, 97498 \\
\hline DBH & 48 & 22,37 & 27,50 & 24,0781 & 1,13338 \\
\hline KKPD & 48 &, 02 & 1,26 &, 1749 &, 20196 \\
\hline $\begin{array}{l}\text { Valid N } \\
\text { (listwise) }\end{array}$ & 48 & & & & \\
\hline
\end{tabular}

Berdasarkan statistik deskriptif variabel penelitian, terlihat bahwa dari 16 kabupaten/kota yang menjadi sampel penelitian, variabel PAD mempunyai nilai rata-rata (mean) sebesar 25,1871 dengan standar deviasi sebesar 0,90018 dimana nilai standar deviasi lebih kecil daripada nilai rata-rata PAD. Demikian pula nilai minimum sebesar 23,21 yang terdapat di Kabupaten Musi Waras tahun 2014 yang lebih kecil daripada nilai rata-ratanya, berbeda dengan nilai maksimum sebesar 27,38 yang terdapat di Kabupaten Musi Rawas utara 2014 yang lebih besar daripada nilai rata-ratanya.

DAU mempunyai nilai rata-rata (mean) sebesar 27,0217 dengan standar deviasi sebesar 0,45686 lebih kecil daripada nilai rata-ratanya DAU. Demikian pula nilai minimum sebesar 25,60 yang terdapat di Kabupaten Musi Banyuasin tahun 2015 yang lebih kecil daripada nilai rata-ratanya, berbeda dengan nilai maksimum sebesar 27,89 yang terdapat di Kota Palembang tahun 2016 yang lebih besar daripada nilai rata-ratanya.

DAK mempunyai mean sebesar 27,0217 dengan standar deviasi sebesar 0,97498 lebih kecil daripada nilai rata-ratanya DAK. Demikian pula nilai minimum sebesar 21,41 yang terdapat di Kabupaten Musi Banyuasin tahun 2015 yang lebih kecil daripada nilai rataratanya, berbeda dengan nilai maksimum sebesar 26,74 yang terdapat di kabupaten OKI tahun 2016 yang lebih besar daripada nilai rata-ratanya.

DBH mempunyai mean sebesar 24,0781 dengan standar deviasi sebesar 1,13338 lebih kecil daripada nilai rata-ratanya DBH. Demikian pula nilai minimum sebesar 22,37 yang terdapat di Kabupaten Musi Rawas Utara tahun 2015 yang lebih kecil daripada nilai rataratanya, berbeda dengan nilai maksimum sebesar 27,50 yang terdapat Di Kabupaten Muara Enim tahun 2014 yang lebih besar daripada nilai rata-ratanya.

KKPD mempunyai mean sebesar 0,1749 dengan standar deviasi sebesar 0,20196 lebih kecil daripada nilai rata-ratanya KKPD. Demikian pula nilai minimum sebesar 0,02 yang 
terdapat di Kabupaten Musi Rawas Utara tahun 2014 yang lebih kecil daripada nilai rataratanya, berbeda dengan nilai maksimum sebesar 1,26 yang terdapat di Kabupaten Musi Banyuasin tahun 2015 yang lebih besar daripada nilai rata-ratanya.

\subsection{Uji Koefisien Determinasi $\left(R^{2}\right)$}

Koefisien Determinasi $\left(\mathrm{R}^{2}\right)$ bertujuan untuk menilai seberapa besar kemampuan model penelitian dalam menerangkan variasi pada variabel dependen. Nilai koefisien determinasi adalah antara nol dan satu. Berikut ini merupakan tabel hasil uji koefisien determinasi:

Tabel 5. Uji Koefisien Determinasi

\begin{tabular}{|l|r|r|r|r|r|}
\hline Model & $\mathrm{R}$ & R Square & $\begin{array}{c}\text { Adjusted R } \\
\text { Square }\end{array}$ & $\begin{array}{c}\text { Std. Error of the } \\
\text { Estimate }\end{array}$ & Durbin-Watson \\
\hline 1 & $.885^{\mathrm{a}}$ & .783 & .763 & .09839 & 1.861 \\
\hline
\end{tabular}

a. Predictors: (Constant), DBH, DAK, PAD, DAU

b. Dependent Variable: KKPD

Sumber: Data sekunder diolah, 2018

Tabel 5 di atas menjelaskan besarnya nilai korelasi/hubungan (R), yaitu sebesar 0,885 yang mengandung pengertian bahwa hubungan variabel-variabel bebas PAD, DAU, DAK dan DBH dengan variabel terikat KKPD termasuk dalam kategori kuat (tabel interpretasi nilai $r$ korelasi terlampir).

Tabel 5 juga menjelaskan besarnya persentase pengaruh variabel-variabel bebas terhadap variabel terikat yang disebut koefisien determinasi yang dapat dilihat pada hasil dari penguadratan R. Dari output tersebut diperoleh koefisien determinasi (Adjusted R Square) sebesar 0,763 yang mengandung pengertian bahwa besarnya pengaruh variabel-variabel bebas PAD, DAU, DAK dan DBH terhadap variabel terikat KKPD adalah 76,3\%. Adapun sisanya $23,7 \%$ dipengaruhi oleh variabel yang lain yang tidak diteliti dalam penelitian ini.

\subsection{Uji Signifikansi Simultan (Uji F)}

Berikut ini merupakan tabel hasil uji F:

Tabel 6. Hasil Uji Statistik F

\begin{tabular}{|l|l|r|r|r|r|c|}
\hline \multicolumn{2}{|l|}{ Model } & $\begin{array}{c}\text { Sum of } \\
\text { Squares }\end{array}$ & Df & Mean Square & F & \multicolumn{1}{c|}{ Sig. } \\
\hline \multirow{3}{*}{1} & Regression & 1.501 & 4 & .375 & 38.762 & $.000^{\mathrm{b}}$ \\
\cline { 2 - 7 } & Residual & .416 & 43 & .010 & & \\
\cline { 2 - 7 } & Total & 1.917 & 47 & & & \\
\hline
\end{tabular}

a. Dependent Variable: KKPD

b. Predictors: (Constant), DBH, DAK, PAD, DAU

Sumber: Data sekunder diolah, 2018

Berdasarkan tabel di atas dapat dilihat nilai $\mathrm{F}$ hitung sebesar 38,762 dengan signifikan sebesar 0,000 lebih kecil dari 0,05, maka hipotesis alternatif diterima. Hal ini berarti PAD, 
DAU, DAK, dan DBH berpengaruh secara simultan terhadap variabel dependennya, yaitu kinerja keuangan pemerintah daerah.

\subsection{Uji Signifikansi Parsial (Uji t)}

Uji statistik t digunakan untuk menunjukkan seberapa jauh pengaruh satu variabel penjelas (independen) secara individual dalam menerangkan variasi variabel dependen (Ghozali, 2013). Untuk mengetahui pengaruh tersebut, digunakan tingkat signifikansi sebesar 5\%. Dari pengujian hipotesis secara parsial diperoleh hasil, yaitu sebagai berikut:

\section{Tabel 7. Hasil Uji Statistik T}

\begin{tabular}{|c|c|c|c|c|c|c|}
\hline \multirow{2}{*}{\multicolumn{2}{|c|}{ Model }} & \multicolumn{2}{|c|}{$\begin{array}{c}\text { Unstandardized } \\
\text { Coefficients }\end{array}$} & \multirow{2}{*}{$\begin{array}{c}\text { Standardized } \\
\text { Coefficients } \\
\text { Beta }\end{array}$} & \multirow[b]{2}{*}{$\mathrm{T}$} & \multirow[b]{2}{*}{ Sig. } \\
\hline & & B & Std. Error & & & \\
\hline \multirow[t]{5}{*}{1} & (Constant) & 3.121 & .859 & & 3.634 & .001 \\
\hline & PAD & .212 & .021 & .943 & 10.244 & .000 \\
\hline & DAU & -.251 & .044 & -.569 & -5.776 & .000 \\
\hline & DAK & -.051 & .017 & -.246 & -3.081 & .004 \\
\hline & DBH & -.009 & .013 & -.048 & -.640 & .525 \\
\hline
\end{tabular}

Sumber: Data sekunder diolah, 2018

Tabel di atas menjelaskan nilai-nilai thitung untuk variabel PAD, DAU, DAK, dan DBH terhadap KKPD Adapun penjelasan dari tabel di atas adalah sebagai berikut:

Nilai $t_{\text {hitung }}$ PAD sebesar10,244 dan nilai $t_{\text {tabel }}$ pada taraf signifikan 0,05 dengan $\mathrm{df}=\mathrm{n}-2$ atau $48-2=46$ adalah 1,67866. Nilai sig. Penelitian adalah 0.000 dan nilai $\alpha=0,05$. Jadi nilai $t_{\text {hitung }}>$ nilai $t_{\text {tabel }}(10,244>1,67866)$ dan nilai Sig. penelitian $<$ nilai $\alpha(0,000<0.05)$. Artinya, terdapat pengaruh positif PAD terhadap kinerja keuangan pemerintah daerah kabupaten/kota di Sumatera Selatan tahun 2014-2016 atau hipotesis $\mathrm{H}_{1}$ diterima.

Nilai thitung DAU sebesar $-5,776$ dan nilai tabel pada taraf signifikan 0,05 dengan $\mathrm{df}=\mathrm{n}-2$ atau $48-2=46$ adalah 1,67866. Nilai sig. Penelitian adalah 0,000 dan nilai $\alpha=0,05$. Jadi nilai $t_{\text {hitung }}>$ nilai $t_{\text {tabel }}(-5,776>1,67866)$ dan nilai Sig. penelitian $<$ nilai $\alpha(0,000<0.05)$. Artinya, terdapat pengaruh negatif DAU terhadap kinerja keuangan pemerintah daerah kabupaten/kota di Sumatera Selatan tahun 2014-2016 atau hipotesis $\mathrm{H}_{2}$ diterima.

Nilai thitung DAK sebesar $-3,081$ dan nilai tabel pada taraf signifikan 0,05 dengan $\mathrm{df}=\mathrm{n}-2$ atau 48-2 $=46$ adalah 1,67866. Nilai sig. Penelitian adalah 0,004 dan nilai $\alpha=0,05$. Jadi nilai $t_{\text {hitung }}<$ nilai $t_{\text {tabel }}(-3,081<1,67866)$ dan nilai Sig. penelitian $<$ nilai $\alpha(0,004<0.05)$. Artinya, terdapat pengaruh negatif DAK terhadap kinerja keuangan pemerintah daerah kabupaten/kota di Sumatera Selatan tahun 2014-2016 atau hipotesis $\mathrm{H}_{3}$ diterima.

Nilai thitung DBH sebesar $-0,640$ dan nilai $t_{\text {tabel }}$ pada taraf signifikan 0,05 dengan $\mathrm{df}=\mathrm{n}-2$ atau 48-2 $=46$ adalah 1,67866. Nilai sig. Penelitian adalah 0,525 dan nilai $\alpha=0,05$. Jadi nilai $t_{\text {hitung }}<$ nilai $t_{\text {tabel }}(-0,640<1,67866)$ dan nilai Sig. penelitian $>$ nilai $\alpha(0,525>0.05)$. Artinya, tidak terdapat pengaruh DBH terhadap kinerja keuangan pemerintah daerah kabupaten/kota di Sumatera Selatan tahun 2014-2016 atau hipotesis $\mathrm{H}_{4}$ ditolak. 
Dengan demikian, secara parsial variabel PAD, DAU, dan DAK yang berpengaruh. Adapun DBH tidak berpengaruh terhadap Kinerja Keuangan Pemerintah Daerah Kabupaten/Kota di Sumatera Selatan tahun 2014-2016.

\subsection{Pembahasan}

4.3.1 Pengaruh PAD terhadap Kinerja Keuangan Pemerintah Daerah Kabupaten/Kota di Sumatera Selatan

Berdasarkan hasil analisis data dapat diketahui bahwa terdapat pengaruh positif PAD terhadap kinerja keuangan pemerintah daerah kabupaten/kota di Sumatera Selatan tahun 2014-2016. Hal ini dibuktikan dengan nilai $t_{\text {hitung }}>$ nilai $t_{\text {tabel }}(10.244>1,67866)$ dan nilai Sig. penelitian < nilai $\alpha(0,000<0.05)$. Hasil ini menjelaskan bahwa daerah dengan PAD yang besar akan cenderung memiliki kinerja yang lebih besar.

Dalam Undang-Undang No. 23 Tahun 2014, PAD merupakan sumber pendapatan daerah yang diperoleh dari wilayah pemerintahan daerah. Sumber PAD adalah berupa pajak daerah, retribusi daerah, pendapatan BUMD dan lain-lain pendapatan daerah yang sah. PAD pada suatu daerah umumnya digunakan sebagai sumber pengeluaran pemerintah daerah PAD berpengaruh positif terhadap alokasi belanja langsung. PAD memiliki peran yang cukup signifikan dalam menentukan kemampuan daerah untuk melakukan aktivitas pemerintah dan program-program pembangunan daerah. Pemerintah mempunyai kewajiban untuk meningkatkan taraf kesejahteraan rakyat serta menjaga dan memelihara ketentraman dan ketertiban masyarakat.

Adanya otonomi daerah yang lebih luas yang diterapkan, menjadikan setiap wilayah memiliki kebijakan dalam mengalokasikan sumber PAD mereka dalam pembangunan daerahnya. Adanya perbedaan permasalahan yang dihadapi oleh masing-masing juga menjadikan alokasi PAD juga berbeda untuk kinerja keuangan pemerintah daerah.

Hasil penelitian ini sesuai dengan hasil penelitian Abdullah dkk (2015), Hamara (2013), dan Prasasti (2014) yang menyatakan bahwa PAD berpengaruh positif terhadap kinerja keuangan pemerintah. Semakin besar kontribusi PAD untuk membiayai pembangunan dan pelayanan masyarakat, maka dapat dikatakan ada peningkatan kinerja keuangan pemerintah daerah. Jika PAD naik, maka dapat dikatakan kinerja keuangan Pemerintah Kabupaten dan Kota naik (meningkat). Dengan demikian, hasil PAD berpengaruh positif terhadap kinerja keuangan pemerintah daerah kabupaten/kota di Sumatera Selatan.

\subsubsection{Pengaruh DAU terhadap Kinerja Keuangan Pemerintah Daerah Kabupaten/Kota di Sumatera Selatan}

Hasil analisis diperoleh terdapat pengaruh negatif DAU terhadap kinerja keuangan pemerintah daerah kabupaten/kota di Sumatera Selatan tahun 2014-2016. Hal ini dibuktikan dengan nilai $t_{\text {hitung }}>$ nilai $t_{\text {tabel }}(-5,776>1,67866)$ dan nilai Sig. penelitian < nilai $\alpha(0,000<0.05)$. Hasil penelitian menunjukkan bahwa DAU yang diperoleh memiliki pengaruh negatif terhadap Kinerja pada Pemerintah Kabupaten/Kota. Hal ini berarti bahwa daerah Kabupaten/Kota yang memiliki dana perimbangan yang tinggi justru memiliki kinerja yang rendah dan penggunaan DAU yang dialokasikan oleh pemerintah pusat belum digunakan dan dimanfaatkan secara efektif dan efisien oleh 
pemerintah daerah sehingga penggunaan dana belum mencapai target untuk kepentingan publik.

Dana perimbangan berasal dari pemerintah pusat berupa DAU, DAK, dan DBH yang berasal dari APBN yang dialokasikan dengan tujuan pemerataan keuangan antar daerah untuk membiayai kebutuhan pengeluarannya di dalam rangka pelaksanaan desentralisasi. Berkaitan dengan perimbangan keuangan antara pemerintah pusat dan daerah, hal tersebut merupakan konsekuensi adanya penyerahan kewenangan pemerintah pusat kepada pemerintah daerah. Dengan demikian, terjadi transfer yang cukup signifikan di dalam APBN dari pemerintah pusat ke pemerintah daerah, dan pemerintah daerah secara leluasa dapat menggunakan dana ini apakah untuk memberi pelayanan yang lebih baik kepada masyarakat atau untuk keperluan lain yang tidak penting. Semakin besar dana perimbangan berupa DAU yang semakin besar yang diberikan oleh pemerintah pusat, maka kontrol terhadap penggunaan dana alokasi tersebut juga akan semakin besar dilakukan oleh pemerintah pusat. Dengan tingginya DAU yang diterima, maka menunjukkan tingkat ketergantungan pemerintah daerah terhadap pemerintah pusat.

Penelitian ini mendukung hasil penelitian dari Prasasti (2014) dan Rukmana (2013) menyatakan bahwa DAU yang merupakan bagian dari dana perimbangan mempunyai pengaruh signifikan negatif terhadap kinerja keuangan pemerintah. Menurut Prasasti (2014), DAU mempunyai pengaruh signifikan terhadap kinerja keuangan pemerintah daerah dikarenakan DAU bagian dari dana perimbangan yang dana transfer dari pemerintah pusat kepada pemerintah daerah dengan tujuan untuk membiayai kelebihan belanja daerah. Apabila realisasi belanja daerah lebih tinggi dari pada pendapatan daerah, maka akan terjadi defisit.

Namun berbeda dengan merupakan penelitian Abdullah dkk (2015) yang menyatakan bahwa DAU yang merupakan bagian dari dana perimbangan tidak mempunyai pengaruh terhadap kinerja keuangan daerah. Dikarenakan terdapat keterikatan pemerintah pusat akan mentransfer dana dalam bentuk dana perimbangan kepada pemerintah daerah. Semakin besar transfer dana perimbangan yang diterima dari pemerintah pusat, maka akan semakin kuat pemerintah daerah bergantung kepada pemerintah pusat guna memenuhi kebutuhan daerahnya, sehingga akan membuat kinerja keuangan pemerintah semakin menurun. Hasil penelitian ini mendukung hasil penelitian Hamara (2013), Rukmana (2013) dan Prasasti (2014) yang menyatakan bahwa DAU bagian dari dana perimbangan berpengaruh negatif signifikan terhadap kinerja keuangan. Dengan demikian, hasil DAU berpengaruh negatif terhadap kinerja keuangan pemerintah daerah kabupaten/kota di Sumatera Selatan.

\subsubsection{Pengaruh DAK terhadap Kinerja Keuangan Pemerintah Daerah Kabupaten/Kota di Sumatera Selatan}

Berdasarkan hasil analisis data dapat diketahui bahwa terdapat pengaruh negatif DAK terhadap kinerja keuangan pemerintah daerah kabupaten/kota di Sumatera Selatan tahun 2014-2016. Hal ini diketahui dari nilai $t_{\text {hitung }}>$ nilai $t_{\text {tabel }}(-3,081>1,67866)$ dan nilai Sig. penelitian <nilai $\alpha(0,004<0.05)$. 
Hasil penelitian menunjukkan bahwa DAK memiliki pengaruh negatif terhadap kinerja pemerintah kabupaten/kota. Hal ini berarti dana perimbangan berupa DAK bukan hasil dari kreativitas dan efektivitas pemerintah daerah melainkan dari pemerintah pusat yang berasal dari APBN yang dialokasikan dengan tujuan pemerataan keuangan antar daerah untuk membiayai kebutuhan khusus yang merupakan kebutuhan daerah dan pengeluaran DAK dalam rangka pelaksanaan desentralisasi, sehingga semakin besar transfer dana perimbangan berupa DAK yang diterima dari pemerintah pusat akan memperlihatkan semakin kuat pemerintah daerah untuk memenuhi kebutuhan daerah dan akan membuat kinerja pemerintah daerah menurun. Hal ini dikarenakan banyaknya aliran DAK dapat memberikan peluang terjadinya kebocoran anggaran, sehingga dapat mengakibatkan adanya penurunan kinerja keuangan pemerintah daerah.

Menurut Abdullah dkk (2015), perolehan dan pemanfaatan DAK oleh daerah harus mengikuti rambu-rambu yang telah ditetapkan oleh Pemerintah Pusat. DAK dialokasikan dalam APBN untuk daerah-daerah tertentu dalam rangka mendanai kegiatan khusus yang merupakan urusan daerah dan termasuk dalam program prioritas nasional. DAK diberikan dengan tujuan untuk membiayai kegiatan-kegiatan khusus pada daerah tertentu yang merupakan urusan daerah dan sesuai dengan prioritas nasional. Khususnya untuk membiayai kebutuhan sarana dan prasarana pelayanan dasar masyarakat yang belum mencapai standar tertentu atau untuk mendorong percepatan pembangunan daerah. Hal ini berarti bahwa semakin tinggi DAK, maka akan semakin tinggi kinerja keuangan pemerintah daerah.

Hasil penelitian ini tidak sejalan dengan penelitian Abdullah dkk (2015) yang menyimpulkan bahwa DAK tidak berpengaruh terhadap kinerja keuangan pemerintah daerah. Hal ini disebabkan karena DAK sama halnya dengan DAU bukan berasal dari kreativitas dan efektivitas pemerintah daerah tetapi DAK berasal dari pendapatan APBN yang dialokasikan pada daerah tertentu untuk membantu mendanai kegiatan khusus yang merupakan urusan daerah dan merupakan bagian dari program yang menjadi prioritas nasional

Adapun perbedaan dari hasil penelitian Hamara (2013), Rukmana (2013) dan Prasasti (2014) menyatakan bahwa DAK secara berpengaruh signifikan terhadap kinerja keuangan pemerintah daerah. Besarnya DAK mampu memberikan peningkatan yang cukup besar terhadap kinerja keuangan pemerintah daerah. Perkembangan realisasi DAK yang terus mengalami peningkatan karena sebagian besar realisasi penerimaan pajak daerah mencapai target yang telah ditetapkan dan sistem pengelolaan sudah berjalan dengan secara optimal akan mampu meningkatkan kinerja keuangan pemerintah daerah.

Bertambahnya aliran DAK ke daerah setiap tahun semestinya disertai rancangan lebih terarah dan pemanfaatannya benar-benar untuk kepentingan rakyat dan bukan rancangan yang memberi peluang terjadinya kebocoran anggaran. Jika kebocoran itu terjadi menunjukkan tingkat kinerja keuangan pemerintah daerah rendah. Dengan demikian, hasil DAK berpengaruh negatif terhadap kinerja keuangan pemerintah daerah kabupaten/kota di Sumatera Selatan. 


\subsubsection{Pengaruh DBH terhadap Kinerja Keuangan Pemerintah Daerah Kabupaten/Kota} di Sumatera Selatan

Hasil dari penelitian ini tidak terdapat pengaruh negatif DBH terhadap kinerja keuangan pemerintah daerah Kabupaten/Kota di Sumatera Selatan tahun 2014-2016. Hal ini dibuktikan dengan nilai $t_{\text {hitung }}<$ nilai $t_{\text {tabel }}(-0.640<1,67866)$ dan nilai Sig. penelitian $>$ nilai $\alpha(0,525>0.05)$.

Hasil penelitian mendapatkan bahwa DBH yang merupakan bagian dari dana perimbangan terhadap kinerja daerah tidak memiliki pengaruh yang signifikan terhadap kinerja daerah. DBH merupakan salah satu bentuk dana perimbangan yang berasal dari pajak dan sumber daya alam yang masuk ke pemerintah pusat. DBH yang diperoleh pemerintah daerah juga menjadi salah satu sumber pengeluaran atau pembelanjaan yang dilakukan daerah. Namun alokasi DBH bagi pembelanjaan daerah sering kali tergantung pada kebijakan pemerintah daerah dan hal ini tidak menjadikan DBH yang tinggi akan menurunkan atau meningkatkan kinerja keuangan pemerintah daerah.

Undang-Undang No. 33 Tahun 2004 menjelaskan bahwa DBH adalah dana yang bersumber dari pendapatan APBN yang dialokasikan kepada Daerah berdasarkan angka persentase untuk mendanai kebutuhan Daerah dalam rangka pelaksanaan desentralisasi. DBH merupakan dana perimbangan yang dimaksudkan untuk membantu daerah dalam mendanai pembangunan, juga bertujuan untuk mengurangi ketimpangan sumber pendanaan antara pemerintahan pusat dan daerah. Apabila realisasi belanja daerah lebih tinggi daripada pendapatan daerah, akan terjadinya defisit. Oleh karena itu, DBH dapat mengatasi ketimpangan tersebut dengan menutupi kekurangan belanja daerah.

Hasil penelitian ini bertentangan dengan penelitian menurut Rukmana (2013) bahwa DBH berpengaruh signifikan terhadap kinerja keuangan pemerintah, karena DBH bagian dari dana perimbangan yang merupakan dana transfer dari pemerintah pusat kepada pemerintah daerah dengan tujuan untuk membiayai kelebihan belanja daerah. Semakin besar transfer dana perimbangan yang diterima dari pemerintah pusat untuk memenuhi kebutuhan daerahnya, maka akan membuat kinerja keuangan pemerintah daerah menurun.

Menurut Hamara (2013), DBH tidak berpengaruh terhadap kinerja keuangan pemerintah daerah. Hal ini disebabkan apabila realisasi belanja daerah tinggi daripada pendapatan daerah, maka akan terjadi defisit. Oleh karena itu, untuk menutup kekurangan belanja daerah, pemerintah pusat mentransfer dana dalam bentuk dana perimbangan kepada pemerintah. Dengan demikian, hasil DBH tidak terdapat berpengaruh terhadap kinerja keuangan pemerintah daerah kabupaten/kota di Sumatera Selatan.

\section{Simpulan}

Berdasarkan pembahasan mengenai pengaruh PAD, DAU, DAK dan DBH terhadap kinerja keuangan pemerintah daerah kabupaten dan kota di Sumatera Selatan, disimpulkan bahwa, Pertama, terdapat pengaruh positif PAD terhadap kinerja keuangan pemerintah daerah kabupaten/kota di Sumatera Selatan tahun 2014-2016. Hal ini menunjukkan semakin besar kontribusi PAD untuk membiayai pembangunan dan pelayanan masyarakat, dapat dikatakan ada peningkatan kinerja keuangan pemerintah 
daerah. Jika PAD naik, maka dapat dikatakan kinerja keuangan pemerintah kabupaten dan kota naik (meningkat). Kedua, terdapat pengaruh negatif DAU terhadap kinerja keuangan pemerintah daerah kabupaten/kota di Sumatera Selatan tahun 2014-2016. Hal ini menunjukkan bahwa semakin tinggi besaran DAU yang diterima dari pusat, maka semakin rendah kinerja keuangan pemerintah daerah. Ketiga, terdapat pengaruh negatif DAK terhadap kinerja keuangan pemerintah daerah kabupaten/kota di Sumatera Selatan tahun 2014-2016. Hal ini dikarenakan banyaknya aliran DAK dapat memberikan peluang terjadinya kebocoran anggaran, sehingga dapat mengakibatkan adanya penurunan kinerja keuangan pemerintah daerah. Jika kebocoran itu terjadi menunjukkan tingkat kinerja keuangan pemerintah daerah rendah. Keempat, DBH tidak mempengaruhi terhadap kinerja keuangan pemerintah daerah kabupaten/kota di Sumatera Selatan tahun 20142016. Hal ini menunjukkan DBH merupakan dana transfer dari pemerintah pusat kepada pemerintah daerah dengan tujuan untuk membiayai kelebihan belanja daerah. Hal ini dikarenakan apabila realisasi belanja daerah tinggi daripada pendapatan daerah, maka akan terjadi defisit. Oleh karena itu, untuk menutup kekurangan belanja daerah, maka pemerintah pusat mentransfer dana dalam bentuk dana perimbangan kepada pemerintah.

\section{Daftar Pustaka}

Abdullah, Asmawanti S, D., \& Febriansyah. (2015). Pengaruh Pendapatan Asli Daerah, Dana Alokasi Umum, dan Dana Alokasi Khusus terhadap Kinerja Keuangan Pemerintah Daerah Kabupaten/Kota se-Sumatera Bagian Selatan. Jurnal Akuntansi, 3 (1):41-67.

Halim, A. (2012). Akuntansi Sektor Publik: Akuntansi Keuangan Daerah. Jakarta: Salemba Empat.

Hamara, K.D. (2013). Pengaruh Dana Perimbangan dan Pendapatan Asli Daerah terhadap Kinerja Keuangan (Studi Kasus di Pemerintahan Kota Tasikmalaya). Jurnal Akuntansi Fakultas Ekonomi Universitas Siliwangi, 1(12): 1-12.

Indriantoro, N. \& Supomo, B. (2011). Metodologi Penelitian Bisnis untuk Akuntansi dan Manajemen. Edisi Pertama. BPFE: Yogyakarta.

Mahmudi. (2010). Manajemen Keuangan Daerah. Jakarta: Penerbit Erlangga.

Mardiasmo. (2009). Akuntansi Sektor Publik. Yogyakarta: Andi.

Prasasti, S.E. (2014). Pengaruh Pendapatan Asli Daerah dan Dana Perimbangan terhadap Kinerja Keuangan Pemerintah Daerah (Studi Kasus Pemerintah Daerah Kabupaten/Kota DIY Tahun 2007-2013). Jurnal Akuntansi Universitas PGRI: Yogyakarta. 
Pemerintah Republik Indonesia. (2004). Undang-Undang Republik Indonesia Nomor 32 Tahun 2004. Pemerintahan Daerah.

Pemerintah Republik Indonesia. (2004). Undang-Undang Republik Indonesia Nomor 33 Tahun 2004. Perimbangan Keuangan antara Pemerintah Pusat dan Pemerintahan Daerah.

Pemerintah Republik Indonesia. (2014). Undang-Undang Republik Indonesia Nomor 23 Tahun 2014. Pemerintahan Daerah.

Rukmana, W.V. (2013). Pengaruh Pajak Daerah, Retribusi Daerah dan Dana Perimbangan terhadap Kinerja Keuangan Pemerintah Provinsi Kepulauan Riau. Jurnal Akuntansi Universitas Maritim Raja Ali Haji: Tanjungpinang.

Sumarsono. (2010). Manajemen Keuangan Pemerintahan. Yogyakarta: Graha Ilmu.

Verawaty. (2017). The Accessibility Determinants of Internet Financial Reporting of Local Government: Further Evidence from Indonesia. World Review of Business Research, 4(2): 176-195.

Verawaty. (2017). Accountability and Internet Financial Reporting of Local Government: An Indonesia Analysis. Lambert Academic Publishing. 